Article

\title{
Planning in the Face of Power. Experiencing Power Dimensions in a Visioning Process in the West Bank and the Gaza Strip
}

\author{
Katharina Gugerell ${ }^{1, *}$ and Stefan Netsch ${ }^{2}$ \\ ${ }^{1}$ Department of Spatial Planning and Environment, Faculty of Spatial Sciences, University of Groningen, \\ 9747AD Groningen, The Netherlands; E-Mail: k.gugerell@rug.nl \\ 2 Department Smart Building and Smart Cities, Salzburg University of Applied Sciences, 5431 Kuchl, Austria; \\ E-Mail: stefan.netsch@fh-salzburg.ac.at \\ * Corresponding author
}

Submitted: 15 January 2017 | Accepted: 13 March 2017 | Published: 28 March 2017

\begin{abstract}
This article reflects on dimensions of power that occurred in visioning workshops with different stakeholder in the West Bank and in the Gaza Strip. The overall argument developed in the article is that the visioning process-especially signs of spatial and institutional dimensions of power-occurred in both cases in a rather similar way, even though the conditions for planning and visioning are significantly different in the West Bank and in the Gaza Strip. The visioning process illustrated that planning indeed shows signs of mediating space and power. Those power struggles are deeply rooted in the Palestinian planning history, the long-standing separation between the Gaza Strip and the West Bank and the protracted conflict between Israel and Palestine. Experiencing oneself the 'dark side of planning' makes clear that planning is not benign and that planning can be a powerful tool for either progressive, pluralistic practices or oppressive ones, as means of regulation and control.
\end{abstract}

\section{Keywords}

conflict; dark side of planning; mobility; Palestine; power; spatial planning

\section{Issue}

This article is part of the issue "Urban Forms and Future Cities", edited by Luca D'Acci (Erasmus University Rotterdam, The Netherlands), Tigran Haas (KTH Royal Institute of Technology, Sweden) and Ronita Bardhan (Indian Institute of Technology Bombay, India)

(C) 2017 by the authors; licensee Cogitatio (Lisbon, Portugal). This article is licensed under a Creative Commons Attribution 4.0 International License (CC BY).

\section{Introduction to Planning in the Palestinian Context}

How does planning work in cities and regions that are contested and conditioned by harsh power asymmetries, occupation (West Bank) or under siege (Gaza strip)? Our reflection on a capacity building and planning project in the Occupied Palestine Territories (West Bank and Gaza) illustrates in a very straightforward way that planning is a highly socio-political activity, strongly related and interlinked with the socio-political environment in which the planning system operates (Rokem \& Allegra, 2016). In the 1990s, Coon $(1990,1992)$ and Altrock (1998) provided a comprehensive standard reference on the West
Bank planning system, which Coon coins as 'planning under occupation'. The occupation has a significant impact on the planning regime, which we will see later, but the situation there is highly different than in Gaza, which is still under siege. From that perspective, the oPt (occupied Palestinian territories) might be a so-called extreme case (Flyvbjerg, 2006), or extreme arena, for the relation of power and space that is mediated by planning (Yiftachel, 2010). In such arenas, politics and the political agenda, such as security or housing matters (Chiodelli, 2012; Hague, 2016; Shmueli, 2005) are translated into plans, policies and institutional designs and communicated. The relation between power and politics has been 
debated in the planning theory, examining planning as a means of regulation, control and subjection of minorities or ethnic groups, which Flyvberg (1996) characterizes as the 'dark side' of planning (e.g. Flyvbjerg, 1996; Flyvbjerg \& Richardson, 2002; Forester, 1990; Hillier, 2002; Huxley, 1994; Marcuse, 1976). Yiftachel (1998) describes four main dimensions of power relations and control: (1) spatial (territorial), (2) institutional dimension (power relations in decision making and procedures), (3) the resulting socio-economic dimension and (4) the cultural dimension. Planners are not decoupled from the field of power. They are neither neutral nor exclusively technical experts (Rokem \& Allegra, 2016), but are actors in this arena practising coalition building, networking, lobbying and political steering (Wagenaar, 2004). The authors also stress the ambiguity, complexity and discrepancy of the institutional decision making process (Hague, 2016; World Bank, 2008). While the official institutions recognise the political dimension of planning and decision making (in terms of Israeli settlements), the reasoning for disapproval of outline plans for Palestinian communities remain purely technocratic (Hague, 2016).

The past and present conflicts between Israelis and Palestinians have created a situation in which the planning and the entire governance system itself is contested (e.g. Coon, 1992; Yiftachel, 2010) and plays an instrumental role in reinforcing the social division and structural processes of discrimination in the popula- tion based on the ethnic origin (e.g. Reuveny, 2003; Salamanca, Qato, Rabie, \& Samour, 2012; Yiftachel, 1998, 2010). These conflicts and constraints become most evident in the fields of urban, spatial and transportation planning, especially around housing and settlement policies and practices (Altrock, 1998; Shalbak, 2013). Almost $75 \%$ of the Palestinian population lives in the urban regions of Gaza and the West Bank (Gaza/ Hebron/Jerusalem/Ramallah/Bethlehem). High population densities with an average of 778 persons $/ \mathrm{km}^{2}$ in the West Bank and 5,000 persons $/ \mathrm{km}^{2}$ in Gaza City are the outcome, peaking at 8,700 persons $/ \mathrm{km}^{2}$, which is comparable to London (see Figure 1).

The urbanization gets amplified by rural-urban migration, better job opportunities (e.g. Nikisic, Nasser Eddin, \& Cali, 2014) and a lesser impairment of daily practices due to mobility restrictions (e.g. El-Atrash, 2016). Scarcity of building land, limited means for mobilising building land complemented by presumed trends towards real estate bubbles (Palestine Economic Policy Research Institute-MAS, 2012) lead to a so-called housing crisis (Palestinian Central Bureau of Statistics [PCBS], $2007,2015 a, 2015 b)$, stressing the little number of affordable houses available. Razeq (2015) reports an average amount of $1,450 \$$ per month necessary to afford good quality housing for a family in Gaza. The number can be contrasted with a $40 \%$ poverty rate, the highest unemployment rate in the world and $70 \%$ of the work-

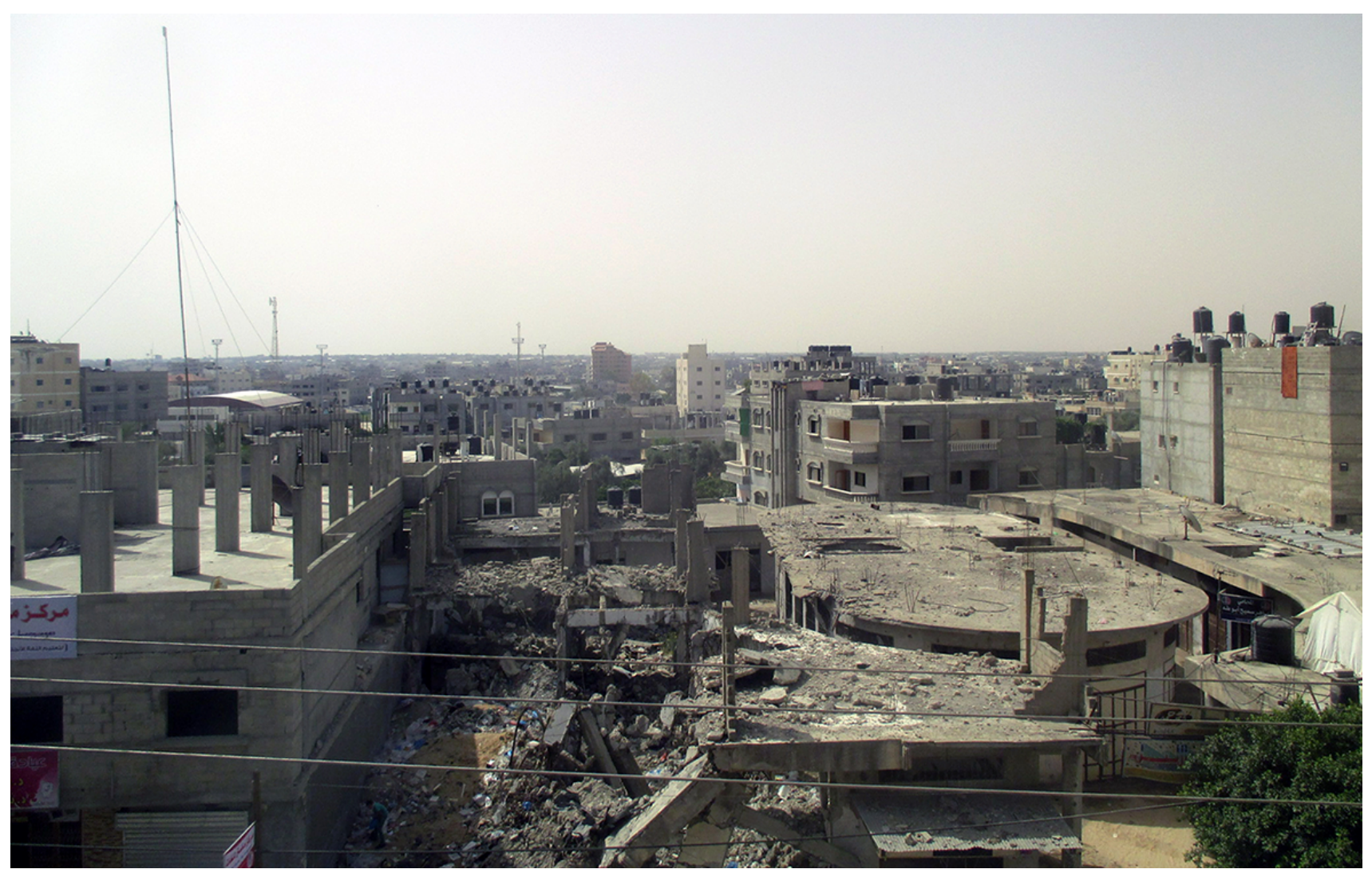

Figure 1. Khan Yunis in the south of the Gaza Strip. Destroyed or ruined buildings are a common impression in the dense urban pattern. 
ing cohort in Gaza being employed in the private sector, earning an average monthly wage of $174 \$$ per person (World Bank, 2015). The discussed responses to housing crises in Gaza include active land management policies, high density solutions, the support of self-organised repair and building activities, land-saving building patterns and price caps for building land as well as reorganised apartment floor plans (e.g. Asfour, 2012). In the West Bank, limited building land resulted in informality (e.g. Alfasi, 2014; Chiodelli, 2012) and construction of buildings without permits, as a result of which they are constantly threatened by demolition and removal (Office for the Coordination of Humanitarian Affairs oPt [OCHA oPt], 2015a). Different studies are exploring the opportunity of polycentric development (Affouneh, 2014) and possible locations for new suburban centres (AbuSada \& Thawaba, 2011) in the metropolitan region Ramallah-Jerusalem. Complementary debates are revolving around micro-scale planning action and the value of insurgent planning (e.g. Porter et al., 2013), community based approaches (e.g. Ibrahim \& Domgjoni, 2015; Jabareen \& Carmon, 2010) and micro socio-spatial practices challenging the spatial logics laid down by the official institutional framework (Gazit \& Latham, 2014). The commonality of those debates is rooted in the general conditions and the planning systems of the two parts of the territory-Gaza strip and the West Bank.

\subsection{Aim and Method}

The aim of this article is to examine and illustrate how spatial and institutional dimensions of power (Yiftachel, 1998) occurred in the planning process of an international design workshop. The study is based on a researchthrough- design approach (Frayling, 1993; Godin, 1993; Stappers, 2007), building on the main assumption that the act of designing has the potential to create insights, skills and knowledge of wicked problems (Rittel, 1972; Rittel \& Webber, 1973). Invited by UN-Habitat and UNDP, two teams of international planners (ISOCARP) were invited to visioning workshops. The aim of those workshops was to reflect with local stakeholders and actors on current challenges and practices and formulate visions for the time of full Palestinian sovereignty including open borders and free movement. The workshops were set up as a mix of different methods, featuring interviews, focus groups, field trips and group discussions with local stakeholders (e.g. municipalities, planning departments, Women's Affair Technical Committee), planning professionals, NGOs (e.g. IPCC, Save Youth Future Society), academia (e.g. An-Najah University, Bard College) and public administration (e.g. Ministry of Local Government, PNSP, Ministry of Transportation). The developed visions are not considered to be future conformance-oriented goals but a means to instigate further discussions and reflections on possible action. The results of the workshops are available in three reports (ISOCARP, 2015a, 2015b, 2016).
The structure of the paper is as follows: In section 2 we introduce the current planning issues in the Gaza Strip and the West Bank that were addressed in the workshop and contextualise them. In section 3 we zoom in on the topic of mobility and transportation and illustrate signs of power dimensions that occurred in the design process. In section 4 we conclude that planning is not benign and that power dimensions are extending to planning practises.

\section{Planning in the West Bank and Gaza Strip}

The situation in the West Bank and in Gaza can be described as a protracted crisis with a declining humanitarian situation (European Commission, 2016), due to the prolonged Israeli occupation, the blockage of the Gaza strip for a decade and the recurring infringement of international law by e.g. settlement activities in the West Bank. In the West Bank vulnerabilities are rooting in occupation policies and military orders (e.g. Coon, 1992; El-Atrash, 2016; OCHA oPt, 2015a), settler violence (e.g. Eiran \& Krause, 2016; Hanauer, 1995) and extension of settlements (e.g. Salamanca et al., 2012), increased number of demolition and increased restrictions on movement. In 2016 a 60\% increase of demolitions and confiscations of Palestinian property and homes, compared to 2015 has been reported (European Commission, 2016). Between 1988 and 2016, 16,087 demolition orders have been issued: thereof 3,344 have been executed, 209 files closed, 9,138 are still in process, 2,909 are on hold due to legal processes and 487 are ready for execution at any given moment (OCHA oPt, 2015b, 2016). Thus, 300,000 people in area C (West Bank total population 2.86 millions) can be considered in constant risk of displacement.

\subsection{West Bank}

The division of the West Bank into the areas A, B and C origins in the 1995 Interim Agreement between the PLO and the Israeli Government. Area A delineates the major preexisting Palestinian urban agglomerations (ca. 18\% WB) and is under full Palestinian jurisdiction and civil control (see Figure 2). Area B are the peri-urban areas surrounding the urban cores of area $A$ or small towns (21\% WB). Area $B$ is under Palestinian civil- and Israeli security control. The 'remaining' $61 \%$ of the West Bank are Area C, which is controlled and governed by the Israeli Civil Administration (ICA)-including all civic matters, such as health or education. This division is also mirrored in the planning system: in areas A and B Palestinian administration is responsible for planning and development issues, while in Area C planning is controlled by ICA, which still strongly focuses on military interests and territorial expansion (see Coon, 1992; UN Habitat, 2015). This division has resulted in an artificial land scarcity because Area $C$ is virtually not available and disposable for the Palestinian communities. Thus, $61 \%$ of the West Bank are inhabited by only $6 \%$ of the $2,649,000$ population 


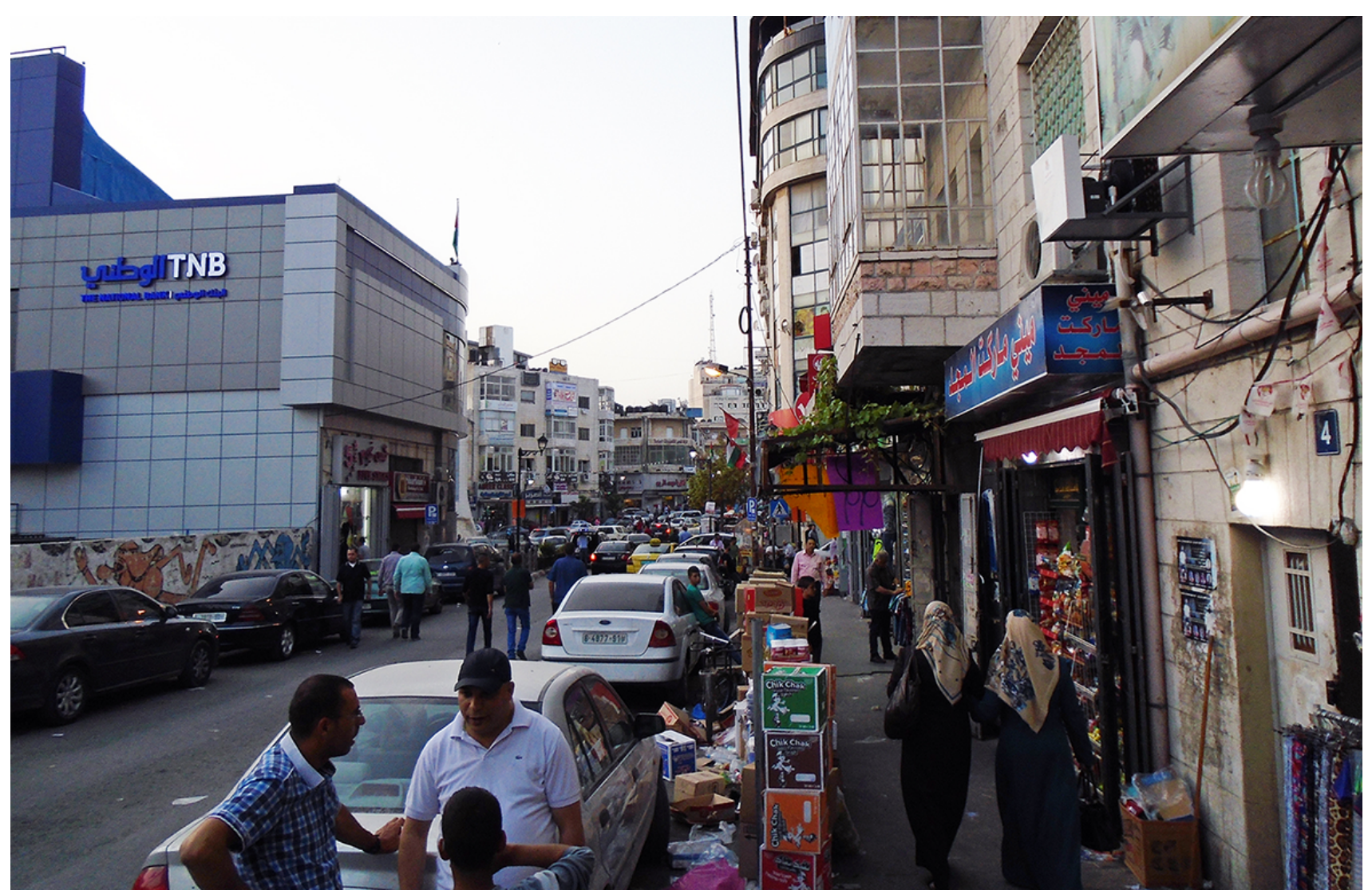

Figure 2. Area A delineates the major pre-existing Palestinian urban agglomerations, such as Ramallah, and is under full Palestinian jurisdiction and civil control.

(additional 628,000 Israeli settlers) since outline plans, the provision with technical infrastructure (e.g. roads, water), issuing of building permits (including refurbishment or upgrading) are executed and controlled by the Israeli administration. Different authors and various UN agencies are reporting on the arbitrary, ambiguous decisions in issuing such permits. OCHA (OCHA oPt, 2015a, 2015b) reports that between 2010 and 2014 only $1.5 \%$ of submitted applications were approved. More recently Hague (Hague, 2016) reported that although local zoning and outline plans match the international technical standards, only three of them were approved and the rest denied based on the alleged technical deficiency. As a result, informal building activities are taking place, additionally enhanced by the artificial land scarcity and arbitrary practices (see also Hague, Crookston, Wegener, Platt, \& Gladki, 2016).

\subsection{Gaza Strip}

In the Gaza Strip (356 $\mathrm{km}^{2}$ ), between Gaza City in the North and Khan Yunis (see Figure 1) in the South, a metropolitan area trends along the Mediterranean Coast (41 km). Entering the $10^{\text {th }}$ year of the 'Gaza blockage', communities are struggling to cope with the complexities of a hostile environment under siege, causing deteriorating socio-economic conditions, confinement of citizens to the Gaza strip (restricted access, movement and exit of citizens and other civics, controlled by Israeli administration), limited trade of goods such as building material required for reconstruction and housing. The last major conflict in 2014 caused approximately 100,000 internally displaced people, 16,000 destroyed housing units (see Figure 3) which are beyond repair (Norwegian Refugee Council, 2015) as well as severe damage to the water and sanitation infrastructure (United Nations Information System on the Question of Palestine [UNISPAL], 2014). The planning and housing situation in the Gaza Strip is severely affected by the past and on-going conflict between Israelis and Palestinians. Reports confirm that whereas the supply of building material became easier, the housing demands are still not met (PCBS, 2015b). Thus, the density in the metropolitan area along the coast is expected to increase further due to population growth and the confinement to the area. Hence, two million people (PCBS, 2015a) that are living in the Gaza Strip are facing daily challenges concerning fragile housing situation, reconstruction, job provision, environmental degradation and the so-called 'SUGI energyfood-water-nexus' (see also Asfour, 2012; Koek, Arafat, \& Clutterbuck, 2015). Still, most of the land remains unregistered resulting in a clandestine land-market and informal transactions. Planning itself is embedded on municipal level, but comprehensive strategies such as legally approved housing policies are still lacking (see also Asfour, 2017). 


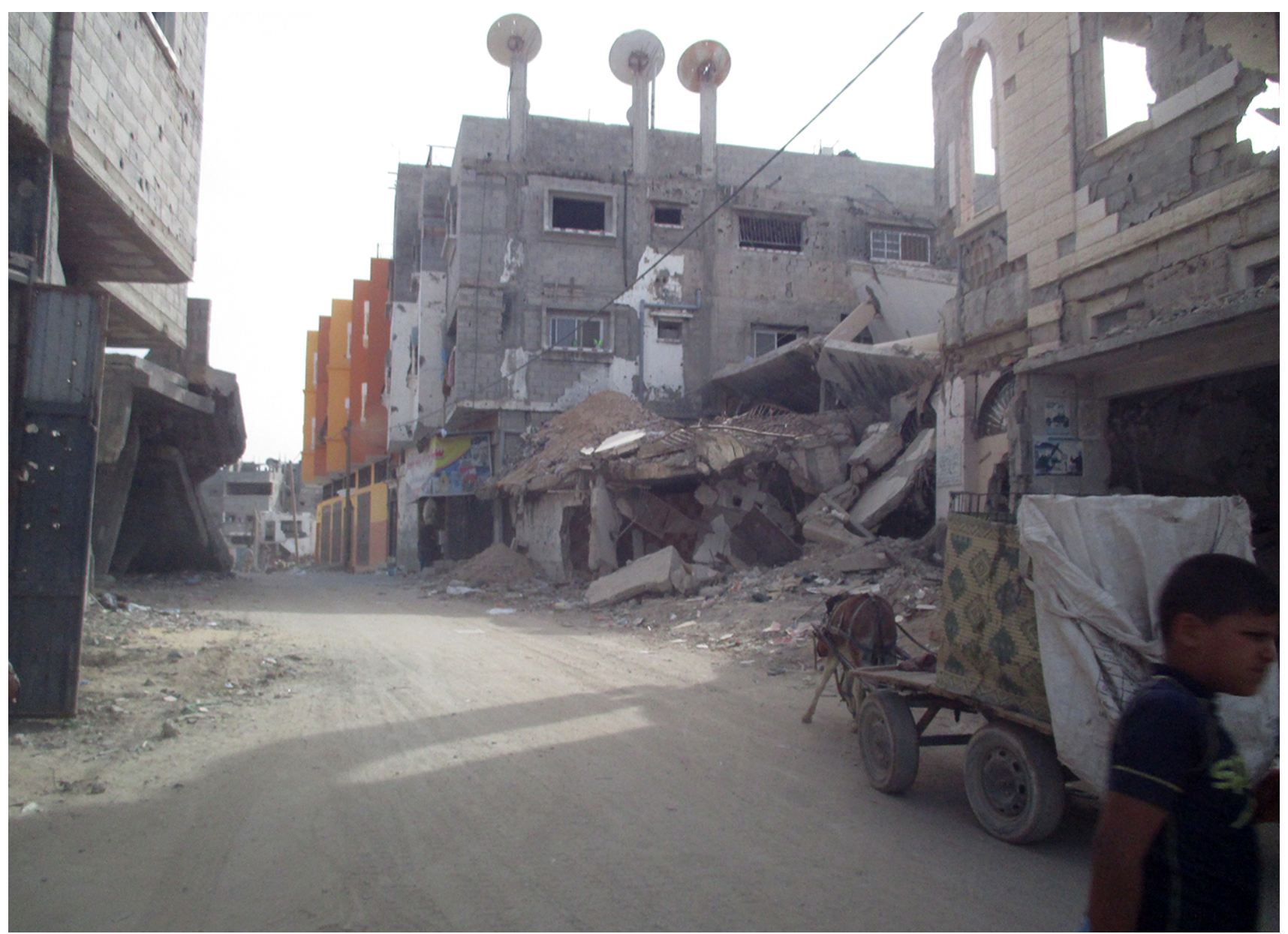

Figure 3. Demolition of housing suburbs in the Gaza Strip.

\subsection{Institutional Framework}

Spatial and urban planning in Palestine stems back to the early $19^{\text {th }}$ century and is a unique assemblage of planning approaches, laws and regulations from different periods and administrations. A comprehensive analysis on the history and difficulties of the Palestinian planning system and its implications on the Palestinian spatial and territorial development are provided by e.g. Coon (1992), Altrock (1998), Shalbak (2013) and El-Atrash (2016). The legal framework governing planning, land tenure and administration goes back to the Ottoman period (1850-1917). During this time, first statuary road and building regulations were implemented. Under the British mandate (1917-1948), town planning was enforced in the British fashion but remained limited to urban areas, such as Jaffa, Haifa, Nablus or Gaza. A hierarchical planning system (central and local level for construction, building permits, roads, etc.) was implemented and later complemented by regional and local plans. After the end of the British mandate, when Jordan annexed the West Bank and Gaza was placed under Egyptian administration, the British planning system and structural plans remained in force. In this time period, land registration was introduced (see also Koek et al., 2015). However, most of the land remained unregis- tered since land owners tried to avoid registration costs and land taxation (Koek et al., 2015) resulting in problems regarding land-tenure, land management and informal housing markets in Gaza, which is commented by an interview partner: "The land ownership system that exists in Gaza is a rather complicated system and it affects future planning" (N. A.). For the West Bank unregistered land is under constant threat of Israeli confiscation, but also attaining building permits is impossible without official land-titles. Israeli occupation (1967) brought a great number of military orders, carried out by the ICA, which superimposed a military governance system over regular civil law (e.g. Coon, 1992; El-Atrash, 2016). However, shortcomings and ill adaptions of the current planning systems are reported:

The second element is related to the packages of laws $\&$ byelaws related to urban issues like planning law, building regulation \& byelaws, stipulation of private land and laws. This legal package inherited from long ago is unsuitable to deal with the actual problems that our cities currently face. When these laws were elaborated and adopted 50-60 years ago, the dimension of socio-economic development was not taken into consideration and it was related just to land use and transportation network. (H. A.) 


\section{Power Dimensions Occurring in the Workshops and Discussions}

One important matter that was addressed in both workshops was the issue of mobility, the future development of urban centres and their connection. In the West Bank workshop, the debates illustrated the impediments and disruptions of daily practices due to the separation wall (see Figure 4), security measures, checkpoints and roadblocks. Additionally, the infrastructure networks are segregated systems: Palestinians are restricted to certain roads and have restricted access to roads in Area C (see Figure 5). One example is the Highway 443 connecting Tel Aviv with Jerusalem, cutting into the West Bank: Palestinians without permits to work or travel inside Israel are not allowed, several Palestinian communities need to take excessive detours to reach Ramallah because of the blocked highway.

The second main design narrative was to conceptualise Ramallah, Jerusalem and Bethlehem as a metropolitan region with complementary qualities and functions. These two topics are strongly interlinked: private transport is cluttering and congesting the cities, dominating the public space and streets. The connections between the cities are organised by a mix of buses, minibuses and shared taxis that have to cross Area $C$ and are thus exposed to mobility restrictions. The importance of developing more sustainable mobility solutions on the re- gional and urban scale was addressed by different workshop participants:

For sure, I mean the road system is the system that is forming now the backbone and will still form the backbone of the transport system to my better understanding. Of course, more should go towards the transit system, for example, the bus rapid transit system, other kinds of mass transit because this will make efficient use. This should be accompanied with policies to restrict the ownership of the vehicles, the automobiles, so on and so forth. This is one of the major developments that we should take into account to develop the roads not specifically only the physical structure of the road but also the kind or the type or the mode of the transportation. We should invest more in the rapid transit or the mass transit or the public transportation. Now beside this, I think there must be also the development of the rail but in a wise manner. I mean rail is very expensive; topography is not very much suitable. You have two kinds of rail-rail for the close communities-urban centres where there is very high demand, then you have the light rail, metro or any other kind of urban rail system. (S. E.)

The proposals developed during the workshop focused on two scales: (a) regional scale, connecting the cities of the metropolitan region in a North-South direction,

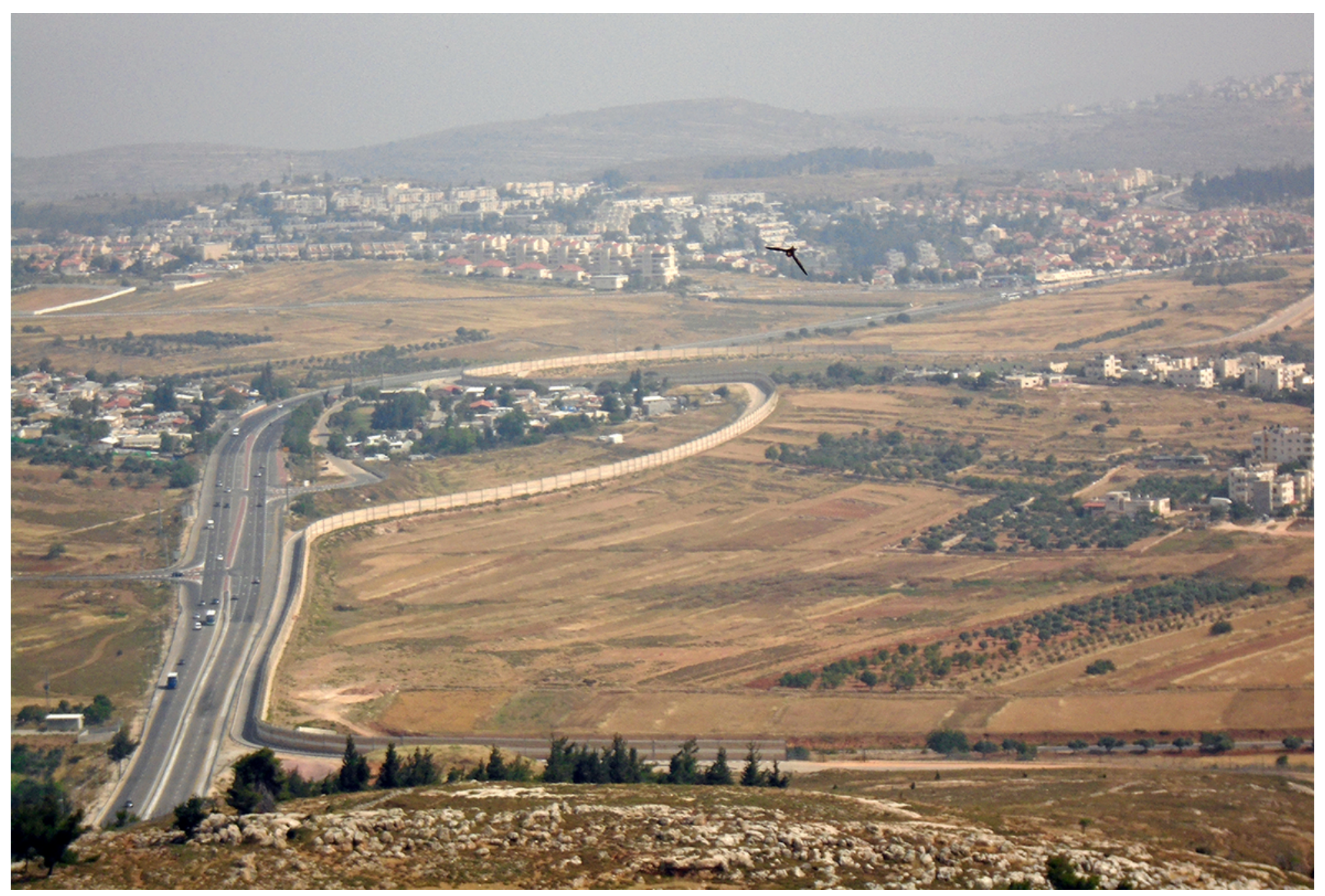

Figure 4. Separation wall cutting through the Palestinian landscape. 


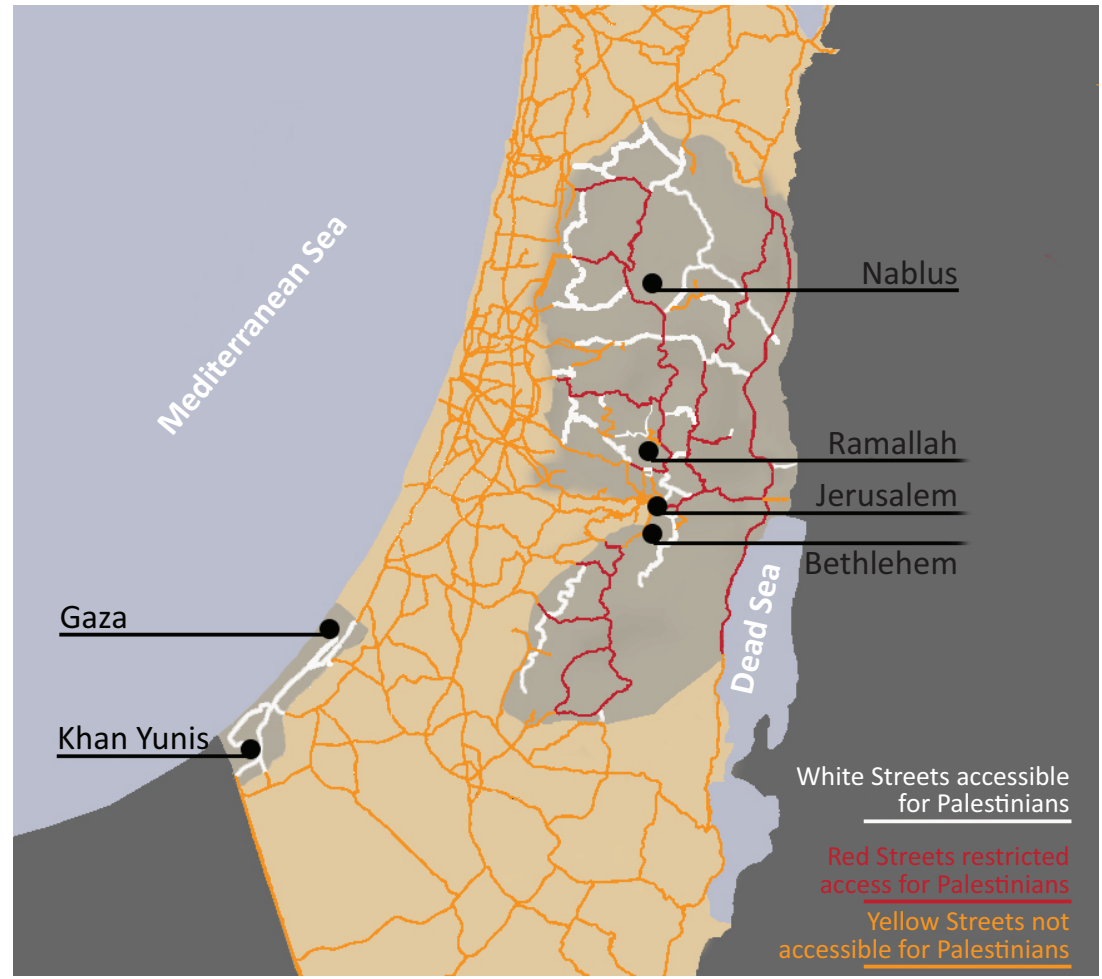

Figure 5. The segregated road-network exacerbates the daily life and practices of the Palestinian population (illustration by authors, based on data from visualisingpalestine.com and ISOCARP, 2015a).

and subsequently considering the future train stations as possible development nuclei on urban scale (b). On the regional scale, a light rail system connecting the major urban centres Ramallah, Jerusalem and Bethlehem was proposed. At the train stations, the local mobility systems are interlinked. Those main routes were outlined as possible areas to increase densities to accommodate the housing demand and connect the different communities and neighbourhoods, which are now rather isolated due to the hilly landscape (see Figure 6).

Another strong debate revolved around the importance of an airport in the West Bank, which was strongly advocated by local planning professionals, representatives of administration and academics:

(...) other modes are needed like the sea, air for connecting Palestine with rest of the world, connecting Gaza Strip with the West Bank in addition to the corridor that is being suggested. We also need to connect people by air between West Bank and Gaza. (S. E.)

Also, something to connect the future state of Palestine with international and regional dimension as to enlarge and redevelop the area of Gaza Airport and to have another regional airport in the West Bank. The latter to be as commercial airport (...) (H. A.)

Yasser Arafat airport, located close to Rafah at the Egyptian border, was built based on the agreements set in the Oslo Accords. It was bombed in 2001 during the al-Aqsa Intifada, and the runway was destroyed in 2002 (see Fig- ure 7). From a strictly technical perspective, the claim for two airports would likely seem elusive, with Tel Aviv and Amman in reach and the design context of free movement and open borders. However, the strong opinions on the importance of airports in the Gaza Strip and West Bank and connecting the people by air between West Bank and Gaza' are owed to the limited freedom of movement within the Palestine territories and the general difficulties and chicaneries for Palestinian at Tel Aviv Airport to leave and return to the country, given they even reach the airport due to frequent road closures. Those mobility impediments make the means of regulation and control evident and can be interpreted as a reaction to the perceived and de-facto non-sovereignty of a community and individuals to make meaningful decisions about their mobility and spatial practices (Flyvbjerg \& Richardson, 2002; Yiftachel, 1998).

Also at the Gaza workshop, mobility and mobility impediment were among the core topics. In the Gaza strip, the urban areas are stringed along the coastal zone with two major centres Gaza (North) and Khan Yunis and Rafah in the South. The current mobility patterns are characterised by individual car traffic and a not wellfunctioning minibus system that is connecting different localities along the coast. The Gaza blockage and limited amount of resources also instigated a strong discussion on future options of mobility and mobility practices. In the case of Gaza, a link to Jerusalem and further to Cairo via an expressway and railway along the eastern border was developed. The location was chosen because it was either still undeveloped or was cleared by the Israeli as 


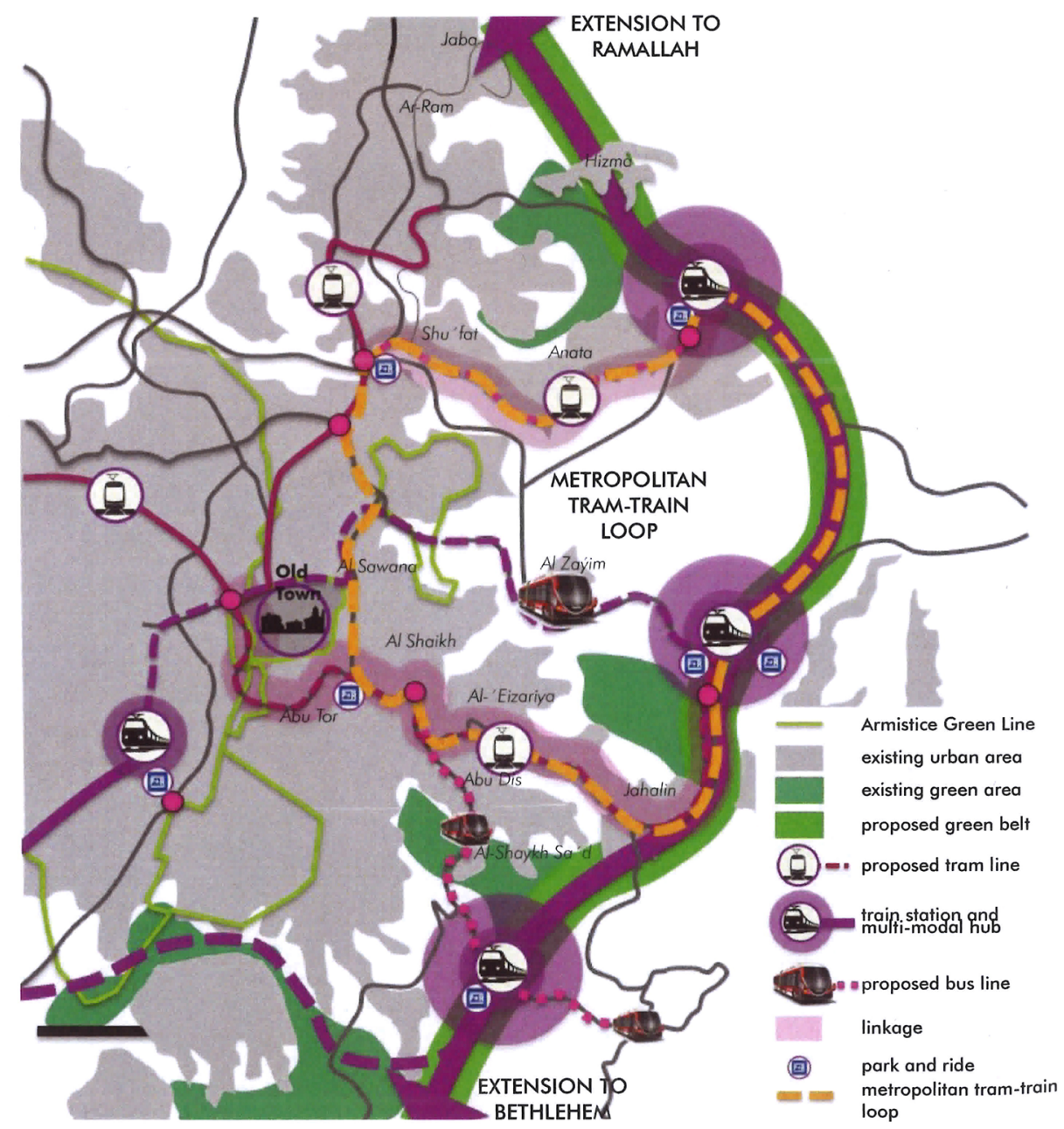

Figure 6. Vision for the metropolitan region Ramallah, Jerusalem and Bethlehem integrating sustainable mobility and urban development (Goethals, 2016).

a consequence of the disengagement in 2005. The historic train path, connecting Gaza with Cairo, still exists, but it is rather underdeveloped and therefore unsuitable for hosting the train track of the strong integration in the built-up area. The stations in Khan Yunis and Gaza are considered as mobility hubs interlinking with the public transport system and to the two seaports. The port in Gaza is seen as logistic centre towards Israel and the one in South as a fishing port. The mobility system is complemented by a biking network located on the former train path. Advocating a resource saving mobility alternative and providing space was considered adequate for the Gaza Strip due to its flat landform (other than in the West Bank).

For the West Bank, particularly strong debates occur on the topic of locating a train line around Jerusalem, especially considering the spatial-political discussions on the Israeli E1 (East1) zone. E1 is a synonym for an Israeli development plan including 15,000 residential homes $\left(12 \mathrm{~km}^{2}\right)$ located within the Palestinian territories in the East of Jerusalem. The plan is contested because there is the threat of increasingly bisecting the West Bank and exacerbating the linkages between East Jerusalem from the rest of the West Bank (see also Hakala, 2012). Even though a very schematic and general vision was developed, several variations and adaptions were necessary to achieve a somewhat politically agreeable version:

Gaza, for example, I look at the proposed railway direction-it is a logical location, but it feels wrongbecause it's near to the border with Israel. But I also know, in the end, it's $6 \mathrm{~km}$-it's going to be either in the east or in the middle, as it was in the past. Or Jerusalem, I do not totally agree with the proposed path of the railway, I prefer a ring road for now, but I think it can be implemented in about ten years. Maybe I do not believe in all the proposed concepts, it's mainly a different perspective. (T. B.)

The discussions demonstrate that spatial debates trigger political debates and reveal power structures. Discussing the track of a railway line or an expressway is less a technical debate. It is rather a debate on the meaning of this line for political negotiation processes and an expression of powerlessness of the Palestinian community to improve their livelihoods via planning. Limited hous- 


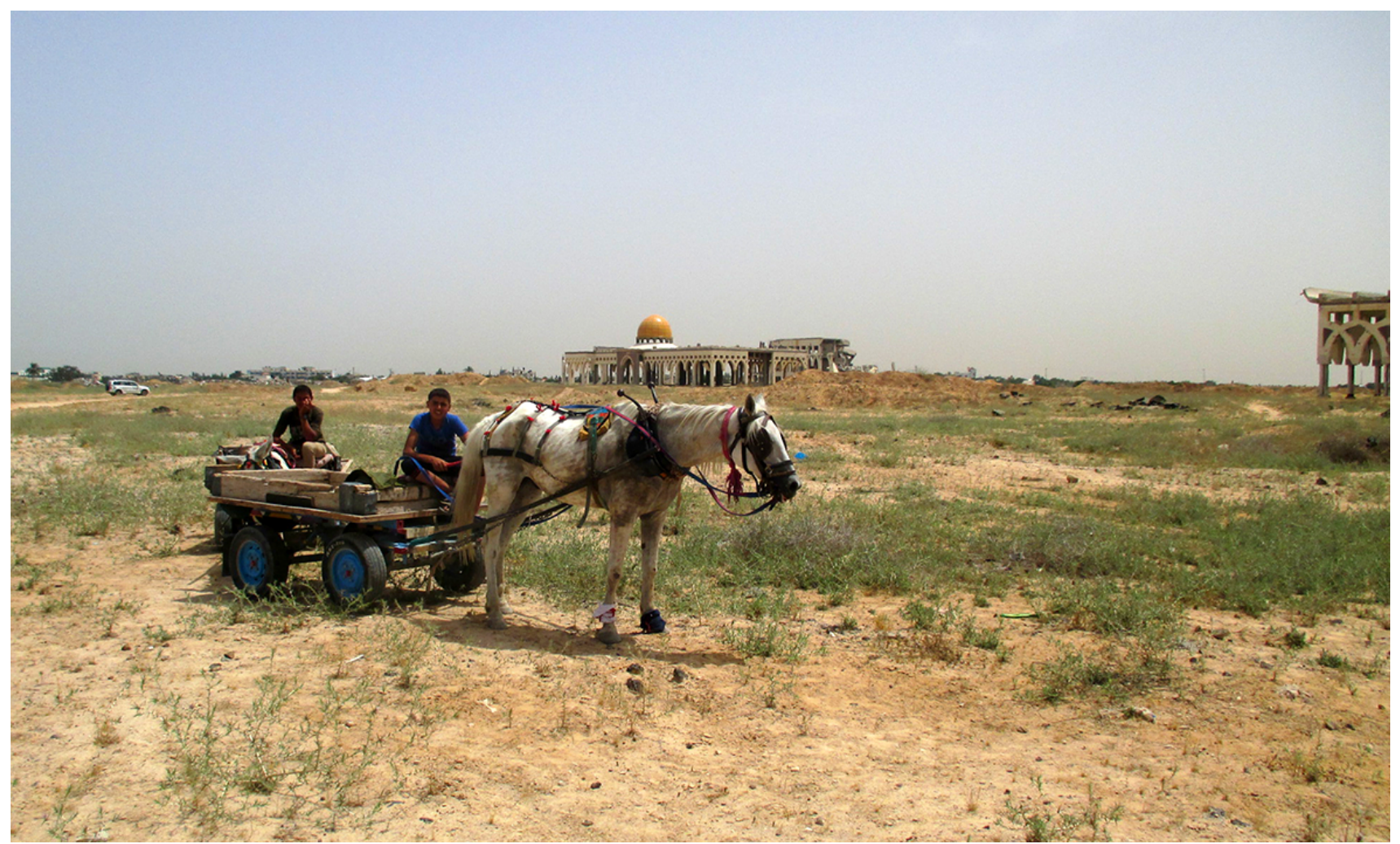

Figure 7. Destroyed Yasser Arafat International Airport at the southern border in the Gaza Strip.

ing opportunities, restricted mobility options, separation walls, containment into a certain area, road blocks, informal housing, demolition of houses and the destruction of spatial structures all indicate the spatial dimension of power and control in the West Bank and in the Gaza Strip (Yiftachel, 1998). As for the institutional dimension of power, we can see that with the lack of landtitles, the institutional framework for Area $\mathrm{C}$ is inhibiting Palestinian authorities from implementing plans and policies and creating a statutory relationship between the authorities and citizens (Forester, 1993). The lack of planning authority in Area $\mathrm{C}$ restricts all spatial initiatives and development plans and also exacerbates the mobility developments that are actually envisaged. Further, it prevents spatial practices of individuals, by rejecting individual applications for building permits. An interview partner commented on this power dimension:

You know what is really bothering me-when you are at a conference and you sit down with the plannersthey consider our case most as 'post-conflict'. I ask then, what does that mean post-conflict? We are not in 'post-conflict' - we are under occupation. It's a difference of thinking in planning-if you want to plan it's not the same. (T. D.)

In the self-governed Areas A and B but also in Gaza, reported institutional ill-adaptations are witnesses of current and historic institutional power struggles, rooting in the various design implements by foreign administrations and occupants.

\section{Concluding Remarks}

As for the relation between power, politics and planning, the West Bank and Gaza are showing similarities. However, we argue that reflecting on such different extreme cases can shed some light on how planning practices and experiences are related with power struggles. The current planning practices are deeply rooted in the longstanding separation of the Gaza Strip and the West Bank. Policies, plans and the planning debate are pervaded by political meaning and subtext, expressing the struggles for recognition and sovereignty to develop plans and implement them. We learned that the power dimensions (Yiftachel, 1998) are extending into the design process itself, so that even plain actions like drawing a line on a conceptual sketch turn into a signifier of power relations and political meaning. We indeed experienced the effects of the "dark side of planning", how planning exercises power in an institutional and spatial environment and create realities on the ground that are impacting and in this case significantly restricting everyday life and social and cultural practices. The example shows that urban, regional and mobility planning practises can be progressive, pluralistic or oppressive and it appears there is a certain naivety and blindness towards the latter, mistakenly believing that planning is per se a positive agent of change. We argue that a critical attitude on actual institutional practises and the structural role that planners play in planning regimes is crucial for working in such contexts. "Should planner speak up?" was the uncomfortable question Cliff Hague (Hague, 2016) asked 


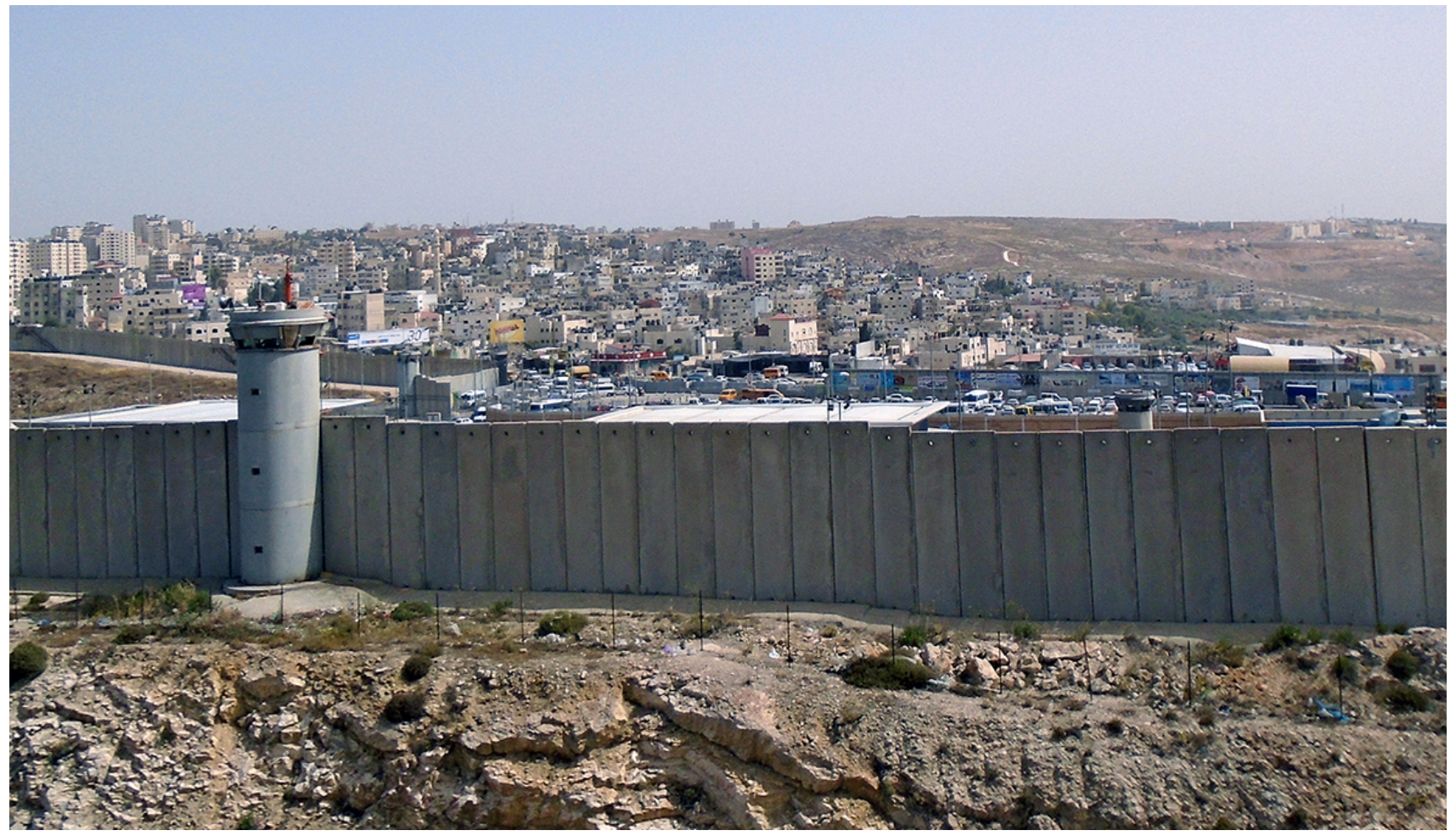

Figure 8. Separation Wall in the West Bank.

the academic community and different planning associations, reflecting on repressive institutional planning practises in the West Bank. 'The philosophers have only interpreted the world in various ways. The point is, however, that planning changes it'-Marx would perhaps answer.

\section{Acknowledgements}

This article is based on the ISOCARP UPAT (organized by Martin Dubbeling) Palestine (2015-2016) co-hosted by UN-Habitat and UNDP. Big thanks to Sebastien Goethals (CITILINKS) who supported this article with his figure from the visioning workshop West Bank. Thanks to the reviewers, who contributed with their comments and feedback.

\section{Conflict of Interests}

The authors declare no conflict of interests.

\section{References}

AbuSada, J., \& Thawaba, S. (2011). Multi criteria analysis for locating sustainable suburban centers: A case study from Ramallah Governorate, Palestine. Cities, 28(5), 381-393. doi:10.1016/j.cities.2011.05.001

Affouneh, N. (2014). Polycentricity as a spatial model for regional development. The case of Ramallah. In $R u$ ral areas: Exploring challenges and opportunities for their conservation and development (pp. 176-220). Birzeit: Birzeit University \& Austrian Development Cooperation.
Alfasi, N. (2014). Doomed to informality: Familial versus modern planning in Arab towns in Israel. Planning Theory \& Practice, 15(2), 170-186. doi:10.1080/ 14649357.2014.903291

Altrock, U. (1998). Stadtplanung in Israel und Palästina. Der Friedensproze $\beta$ als Neubeginn? (Arbeitsheft). Berlin: Technische Universität Berlin.

Asfour, O. S. (2012). Towards an effective strategy to cope with housing land scarcity in the Gaza Strip as a sustainable development priority. Habitat International, 36(2), 295-303. doi:10.1016/j. habitatint. 2011.10.005

Asfour, O. S. (2017). The role of land planning policies in supporting housing affordability: The case of the Gaza Strip. Land Use Policy, 62, 40-48. doi:10.1016/ j.landusepol.2016.12.018

Chiodelli, F. (2012). Planning illegality: The roots of unauthorised housing in Arab East Jerusalem. Cities, 29(2), 99-106. doi:10.1016/j.cities.2011.07.008

Coon, A. (1990). Plans in the West Bank. GeoJournal, 21(4), 363-373.

Coon, A. (1992). Town planning under military occupation. Aldershot: Dartmouth Publishing.

Eiran, E., \& Krause, P. (2016). Old (Molotov) cocktails in new bottles? "Price-tag" and settler violence in Israel and the West Bank. Terrorism and Political Violence, 6553(July), 1-21. doi:10.1080/09546553. 2016.1194271

El-Atrash, A. (2016). Implications of the segregation wall on the two-state solution. Journal of Borderlands Studies, 31(3), 365-380. doi:10.1080/08865655. 2016.1174594 
European Commission. (2016). Humanitarian aid and civil protection Palestine. Brussels. Retrieved from http://ec.europa.eu/echo/files/aid/countries/factsh eets/palestine_en.pdf

Flyvbjerg, B. (1996). The dark side of planning: Rationality and "relationality." In S. J. Mandelbaum, L. Mazza, \& R. W. Burchell (Eds.), Explorations in planning theory (pp. 383-397). New Brunswick: Rutgers University Press.

Flyvbjerg, B. (2006). Five misunderstandings about casestudy research. Qualitative Inquiry, 12(2), 219-245. doi:10.1177/1077800405284363

Flyvbjerg, B., \& Richardson, T. (2002). Planning and Foucault. In search of the dark side of planning theory. In P. Allmendinger \& M. Tewdwr-Jones (Eds.), Planning futures: New directions for planning theory (Vol. 7, pp. 44-63). London \& New York: Routledge. doi:10.1177/1473095208090432

Forester, J. (1988). Planning in the face of power. Berkeley, CA:University of California Press.

Forester, J. (1993). Critical theory, public policy, and planning practice. Albany, NY: SUNY Press.

Frayling, C. (1993). Research in art and design. Royal College of Art Research Papers, 1(1), 1-6.

Gazit, N., \& Latham, R. (2014). Spatial alternatives and counter-sovereignties in Israel/Palestine. International Political Sociology, 8(1), 63-81. doi:10.1111/ ips.12040

Godin, D., \& Zahedi, M. (2014). Aspects of research through design: A literature review. Proceedings of DRS, 1667-1680.

Goethals, S. (2016). A progressive path to accessibility. PLAN, 3, 31-36. The Hague: ISOCARP.

Hague, C. (2016). Planning practice in the West Bank: Should planners speak up? Planning Theory \& Practice, 17(1), 161-165. doi:10.1017/CBO978110 7415324.004

Hague, C., Crookston, M., Wegener, M., Platt, C., \& Gladki, J. (2016). Why planning needs to change in the occupied West Bank. UN-HABITAT oPT. Retrieved from https://unhabitat.org/spatial-planning-in-areac-of-the-israeli-occupied-west-bank-of-the-palestini an-territory/

Hakala, P. (2012). Removing Bedouins from Jerusalem's outskirts, jeopardising the two-state solution (Quick policy insight). Luxembourg: European Parliament.

Hanauer, L. S. (1995). The path to redemption: Fundamentalist Judaism, territory and Jewish settler violence in the West Bank. Studies of Conflict and Terrorism, 18(245-270).

Hillier, J. (2002). Shadows of power: An allegory of prudence in land-use planning. London: Routledge.

Huxley, M. (1994). Planning as a framework of power: Utilitarian reform, enlightenment logic and the control of urban space. In S. Ferber, C. Healy, \& C. McAuliffe (Eds.), Beasts of suburbia: Reinterpreting cultures in Australian suburbs (pp. 148-169). Carlton, VIC: Melbourne University Press.
Ibrahim, A. (2015). Placemaking in the West Bank in Area C. PLAN, 1, 59-62.

ISOCARP. (2015a). Spatial visioning reflections. The heartland of the West Bank. PLAN, 1. The Hague: ISOCARP.

ISOCARP. (2015b). Spatial visioning reflections. Gaza Coast. PLAN, 2. The Hague: ISOCARP.

ISOCARP. (2016). Spatial visioning reflections. Palestine. PLAN, 3. The Hague: ISOCARP.

Jabareen, Y., \& Carmon, N. (2010). Community of trust: A socio-cultural approach for community planning and the case of Gaza. Habitat International, 34(4), 446453. doi:10.1016/j.habitatint.2009.12.005

Koek, E., Arafat, J., \& Clutterbuck, M. (2015). Rebuilding from the rubble: Post-conflict land tenure challenges and opportunities in the Gaza Strip. Paper presented at the 2015 World Bank Conference on Land and Poverty.

Marcuse, H. (1976). Professional ethics and beyond: Values in planning. Journal of the American Institute of Planners, 42, 264-294.

Palestine Economic Policy Research Institute-MAS. (2012). The construction sector in the Palestinian territory: Is there real estate bubble? Ramallah: MAS.

Nikisic, O., Nasser Eddin, N., \& Cali, M. (2014). West Bank and Gaza-Area C and the future of the Palestinian economy. Washington D.C.: International Bank for Reconstruction and Development / The World Bank. http://doi.org/10.1596/978-1-4648-0193-8

Norwegian Refugee Council. (2015). Rental rights and responsibilities in Gaza (Gaza Housing, Land and Property Rights Series, Fact Sheet 7). Oslo: Norwegian Refugee Council.

Office for the Coordination of Humanitarian Affairs oPt. (2015a). Under threat. Demolition orders in Area C of the West Bank (Vol. 972). East Jerusalem: OCHA oPt.

Office for the Coordination of Humanitarian Affairs oPt. (2015b). Humanitarian response plan. East Jerusalem: OCHA oPt.

Office for the Coordination of Humanitarian Affairs oPt. (2016). Israeli demolition orders against Palestinian structures in Area C, 1988-2016. East Jerusalem: OCHA oPt. Retrieved from http://data.ochaopt.org/ demolitions/index.aspx?id=311650

Palestinian Central Bureau of Statistics. (2007). A statistical report about land use statistics in the Palestinian Territory. Ramallah: PCBS.

Palestinian Central Bureau of Statistics. (2015a). Palestine in figures 2014. Ramallah: PCBS.

Palestinian Central Bureau of Statistics. (2015b). Statistical yearbook of Palestine. Ramallah: PCBS.

Porter, L., Martí-Costa, M., Torvà, M. D., Cohen-Bar, E., Ronel, A., Rogers, D., . . de Hoop, H. (2013). Finding hope in unpromising times: Stories of progressive planning alternatives for a world in crisis. Planning Theory \& Practice, 14(4), 529. doi:10.1080/ 14649357.2013.853470

Razeq, O. A. (2015). Housing market in Palestine: Supply and demand and prices. Ramallah: MAS. 
Reuveny, R. (2003). Fundamentalist colonialism: The geopolitics of Israeli-Palestinian conflict. Political Geography, 22(4), 347-380. doi:10.1016/S0962-6298 (02)00114-2

Rittel, H. (1973). The state of the art in design methodology. Design Research and Methods, 7(2), 143-147.

Rittel, H., \& Webber, M. (1973). Dilemmas in a general theory of planning. Policy Sciences, 4(2), 155-169.

Rokem, J., \& Allegra, M. (2016). Planning in turbulent times: Exploring planners' agency in Jerusalem. International Journal of Urban and Regional Research, 40(3), 640-657. doi:10.1111/1468-2427.12379

Salamanca, O. J., Qato, M., Rabie, K., \& Samour, S. (2012). Past is present: Settler colonialism in Palestine. Settler Colonial Studies, 2(1), 1-8. doi:10.1080/ 2201473X.2012.10648823

Shalbak, M. (2013). Mauern: Konsequenzen aus künstlichen Trennungen in städtischen und regionalen Agglomerationen. Israelische Trennungsstrategien und ihre Folgen für Raumentwicklung in den palästinensichen Gebieten. Karlsruhe: Karlsruhe Institute of Technology.

Shmueli, D. F. (2005). Is Israel ready for participatory planning? Expectations and obstacles. Planning Theory \& Practice, 6(4), 485-514. doi:10.1080/ 14649350500349656
Stappers, P. J. (2007). Doing design as a part of doing research. In R. Michel (Ed.), Design research now: Essays and selected projects (pp. 81-91). Basel: Birkhäuser.

UN Habitat. (2015). 'One UN' approach to spatial planning in "Area C" of the occupied West Bank. Ramallah: UN-Habitat Palestine.

United Nations Information System on the Question of Palestine [UNISPAL]. (2014). Gaza water disaster: Damages to water infrastructure.

Wagenaar, H. (2004). "Knowing" the rules: Administrative work as practice. Public Administration Review, 64(6), 643-665. doi:10.1111/j.1540-6210. 2004.00412.x

World Bank. (2008). West Bank and Gaza-The economic effects of restricted access to land in the West Bank. Washington, DC: World Bank Group.

World Bank. (2015). Economic monitoring report to the ad hoc liaison committee. Washington, DC: World Bank Group.

Yiftachel, O. (1998). Planning and social control: Exploring the dark side. Journal of Planning Literature, 12(4), 395-406.

Yiftachel, O. (2010). From Sharon to Sharon: Spatial planning and separation regime in Israel/Palestine. $\mathrm{Ha}$ gar, 10(1), 71.

\section{About the Authors}
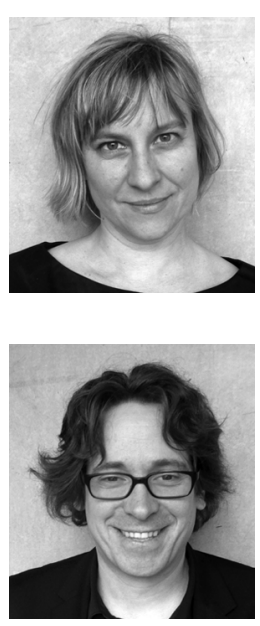

Katharina Gugerell is Assistant Professor in Planning and Spatial Design at the Department of Spatial Planning and Environment, University of Groningen, The Netherlands. Current research topics include Living Labs as experimental forms of governance, games and playful approaches and methods in planning and power-dimensions in governance networks. She teaches at different universities in the Netherlands, Austria and China.

Stefan Netsch is Senior Researcher at the Salzburg University of Applied Sciences, Austria. He is currently involved in research projects on revitalisation and refurbishment on neighbourhood and district scale. He is author of the textbook Stadtplanung. Handbuch und Planungshilfe and is finishing his $\mathrm{PhD}$ thesis investigating strategies for re-use and follow-up use of churches in the Netherlands and Germany. 